\title{
Implementation of Odoo for Managing Safety Stock in Clothing Retail Industry
}

\author{
Nyoman Bayu Pramana \\ Udayana University \\ Engineering Faculty \\ Department Information \\ Technology
}

\author{
I. Putu Agung Bayupati \\ Udayana University \\ Engineering Faculty \\ Department Information \\ Technology
}

\author{
I. Ketut Adi Purnawan \\ Udayana University \\ Engineering Faculty \\ Department Information \\ Technology
}

\begin{abstract}
This application of Odoo in Enterprise Resource Planning (ERP) is performed by Small Medium Enterprise (SME) $\mathrm{XYZ}$, which is a clothing retail industry that sells T-shirt as the products. The current problem faced by SMEs is in making goods purchase orders which are still done manually. Hence, there is often an error in the amount of stock to be ordered because it does not adjust with the existing demand. As a result, there is a decrease in sales and obstruction of the production process. A solution to this problem is to develop a Business Process Management (BPM) by creating an automated goods purchase order system based on existing demand, therefore the availability of goods is more scheduled. For this reason, ERP technology named Odoo is implemented which provides a Community version and is open-source to develop new business processes. Odoo Community version 11.0 is used in this study by applying two modules, Inventory and Purchase. Reordering rules are safety stock rules that apply to Odoo. The 'run scheduler' feature in the Inventory module automatically runs the reordering rules system that exists in the product. After applying Odoo to the mentioned SME, a questionnaire is made in order to evaluate the readiness of the company in accepting ERP technology by using the Technology Acceptance Model (TAM) method and Likert scale. The results of the survey showed a value in the 'perceived ease of use' variable is around $60 \%$ and $80 \%$ in the 'perceived usefulness' variable. This study provides an overview of how SME XYZ develop BPM from old business processes into best-practice forms by implementing business processes on Odoo. In addition, to evaluate the level of acceptance of Odoo ERP technology in similar SMEs in the clothing retail industry.
\end{abstract}

\section{Keywords}

Enterprise Resource Planning, Supply Chain Management, Reordering Rules, Odoo 11.0.

\section{INTRODUCTION}

Entering industry 4.0 technological and information development in Indonesia has been rapidly developed. This development brings positive effects for society and also companies like SMEs in Indonesia. According to data from Kominfo.go.id, in 2017 noted that the total SMEs in Indonesia is around 59,2 million and around 3,79 million SMEs have utilized technology for purchasing needs. Based on that data, it can be known that around $92 \%$ of SMEs is still used the conventional system to manage all process business needs in it. The companies that are case studies in this research are SMEs engaged in the clothing retail industry. The current system has not implemented information technology that can save work, so it often causes problems such as recording errors in the purchase and sale of goods and also the management of the availability of goods that are slow.

Improving process business quality in a big company or SMEs need information technology that can integrate all data between departments and can be accessed quickly. One information technology needed is ERP or Enterprise Resource Planning. ERP is a software program used by organizations or companies to integrate and coordinate information in every area of the business [1]. ERP supports to create an efficient business process operation by connecting tasks in each department such as sales, marketing, manufacture, logistics, accounting, and human resources [1]. Management of all departments in the company can be controlled on one ERP application, making it easier to integrate data and information needed.

There are various models of ERP application such as Odoo, SAP, NetSuite, Oracle's E-Business Suite, and many more. One of ERP technology that is properly used by big or small companies is Odoo. Odoo is a modern ERP application that has been used by 4 million users worldwide and equipped with 38 open-source modules in Odoo version 11.0. There are four modules used in this research, such as Sales, Invoicing, Inventory, and Purchase. Odoo has a user-friendly and good business scope compared to other ERP applications.

The integration capabilities of Odoo support companies or SMEs to create new and efficient business processes, compared to conventional systems [1]. One example of the problem is in the management of stock availability so that it is always available at all times to meet sales demand or production needs of goods [2]. Conventionally SMEs must examine goods availability manually to see the stock which is minimum and then conduct goods purchasing. When conducting goods purchasing, often happen excess or lack of stock, because it is not adjusted to the product demands as a result, there is a decline of sale, the production process is hampered, and the company suffers losses from buying too many items. The solution to this problem is to use the Odoo application. The integrated modules in the Odoo application make it easy for SMEs to manage the availability of goods with the reordering rules feature and the item availability scheduling system in the run scheduler feature in the Inventory module. The reordering rules feature helps the business actors to manage then total minimum and maximum of goods stock to make it stored in a warehouse. When the company runs run scheduler function, then automatically Odoo makes a purchase order document for a total of goods that is under the stock minimum. The company is no longer need to make a purchasing document manually because it has been made automatically by Odoo system. Besides, ease the task of examining the availability of goods manually, because 
everything is set in the Odoo application.

\section{RESEARCH METHODOLOGY}

Research concerning Business Process Management (BPM) in
SMEs used software ERP which is Odoo. The analysis plot of this research consists of six stages which are literature study, data collection, data processing, data analysis, system test and implementation, also conclusion and suggestion.

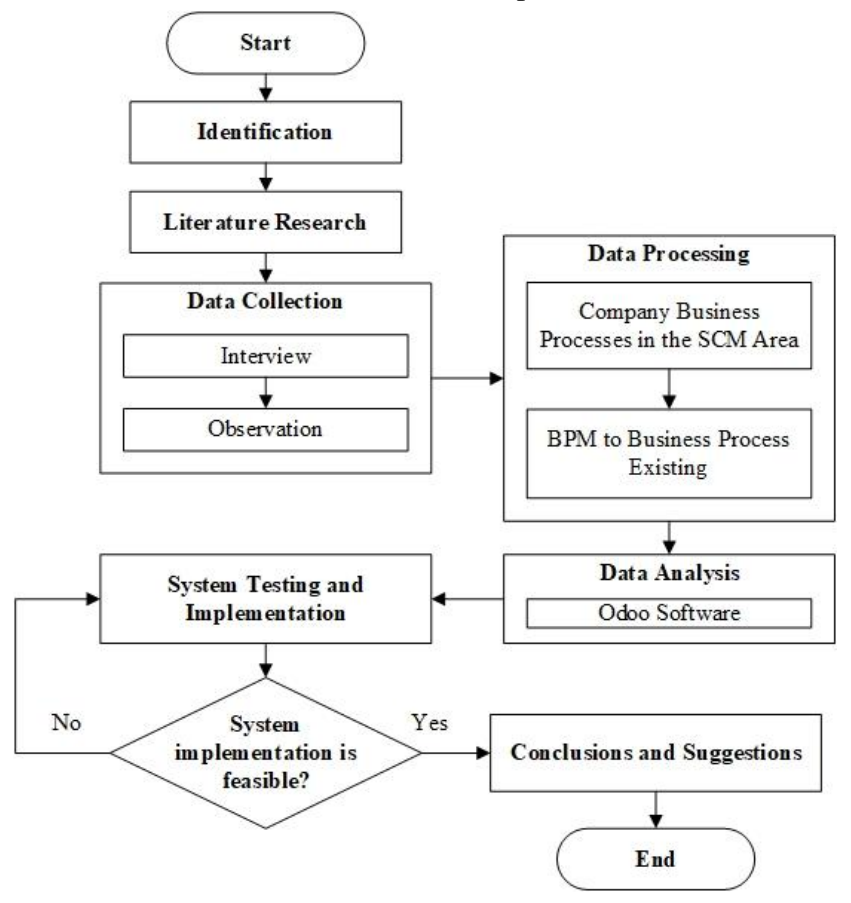

Fig. 1: Research Methodology

Determine the problems that occur in the area of supply chain management in a company. After finding the problem model, it is continued by collecting several theories, methods or models related to research problem which is conducted that are ERP, BPM, and software Odoo. The resources of literature study used are from books, journals, articles, and scientific researches to give basic theory and references for the research direction.

The data collection methodology was conducted through interview and observation. The interview was conducted by question and answer directly to company manager who work in the fields of sale, storage, purchase, and others. The observation was conducted by direct observation to business process, procedure, and problems that inhibit the business performance.

Data that has been obtained from data collection was processed to find out the Business Process Existing in the field of SCM which is then made Business Process Management (BPM) from the Business Process Existing.

Data analysis was conducted with Business Process Management (BPM) towards changes and improvement of company business process using software ERP which is Odoo. This Software is used as research basis because the running ERP system has implemented best-practice business process.

Testing and implementation of system was conducted to test the feasibility of company business process based on data analysis result. The research stages were conducted with trial to new system towards the old system. If this trial is successful and feasible to be used by the company, the research stage will continue to the conclusions and suggestions stage. If the system is still not feasible, then retest the system to meet the needs of the company.
This stage contains of conclusion and result of research conducted. Suggestion stage explains the things that can be conducted for the further research.

\section{REVIEW OF LITERATUR}

Enterprise Resource Planning or ERP is a computer system that is used to integrate each business area in a company to coordinate data and information [1]. This system is an innovation that can help the company to improve the performance and data processing, distribution, human resource, hardware, software, and service standard through the use of new method [3]. This software is also used to ease organization in managing business process in each department and make management reporting for all business areas in one database [4]. ERP software supports efficient business operation process by integrating business functions in each department such as sale, marketing, manufacture, logistic, accountancy, and staffing $[1,5]$. One of ERP system is Odoo. Odoo is ERP software which is open source that is previously named OpenERP. Odoo has integrated modules, such as Sales Management, Invoicing, Inventory, Purchase, Manufacturing modules and several other modules to manage all company departments, so that communication between department in data and information exchanges become easier. A company can make new business process by implementing BPM or Business Process Management with module in Odoo. BPM is a management technique that is focused to identify, illustrate, and control the business process of an organization [6]. In addition, BPM is also used to implement information system in aligning with company strategy $[6,7]$. BPM is much used by organization or company to improve the business process in customer services to make it more efficient [6]. Therefore, in order to find out the company's readiness in accepting ERP technology named Odoo, a survey based on the theory of Technology Acceptance Model (TAM) was performed by using a Likert scale. TAM is a theory proposed by Fred D. 
Davis in 1989 which mention the use of information technology systems to evaluate technology acceptance [8]. There are two variables used in this questioner, namely perceived ease of use and perceived usefulness [9]. The perceived ease of use is applied in order to find out the extent to which someone believes that the use of ERP technology is easily applied in works [8]. There are three statements that are made on the variable of perceived ease of use, namely ease of use, ease to learn, and understandable [10]. The perceived of usefulness refers to the extent of someone's belief in ERP technology $[8,11]$, which can improve the quality of work in the Inventory and Purchase department. There are five statements that are made on the variable of perceived of usefulness, namely work more quickly, makes work easier, increase productivity, effectiveness, and job performance [10]. The Likert scale consists of five assessment levels that will be chosen by respondents, namely strongly disagree with a score of 1 , disagree with a score of 2 , neutral with a score of 3 , agree with a score of 4 and strongly agree with a score of 5 .

\section{IMPLEMENTATION}

The implementation is conducted by fist configure the Odoo, then analyze the business process that have been implemented and create a new business process system based on the ERP concept on the Odoo system. The purpose of this implementation is to find out the differences between existing business processes and proposed business process.

\subsection{General Description of the System}

In general, this implementation uses five modules, namely Sales, Invoicing, Manufacturing, Inventory, and Purchase. Each of these modules is used by users with different access rights, such as the sales module is used by Sales Managers and Users; the invoicing module is used by Accounting \& Finance Managers and users; the manufacturing module is used by Manufacture Managers and Users. This research only focuses on the use of two modules, such as Inventory and Purchase. Each module also has users with different access rights. This implementation involves two employees from the Warehouse department as item management namely Inventory Manager and User, and also two employees from the goods purchasing department as raw material purchasing management namely Purchase Manager and User.

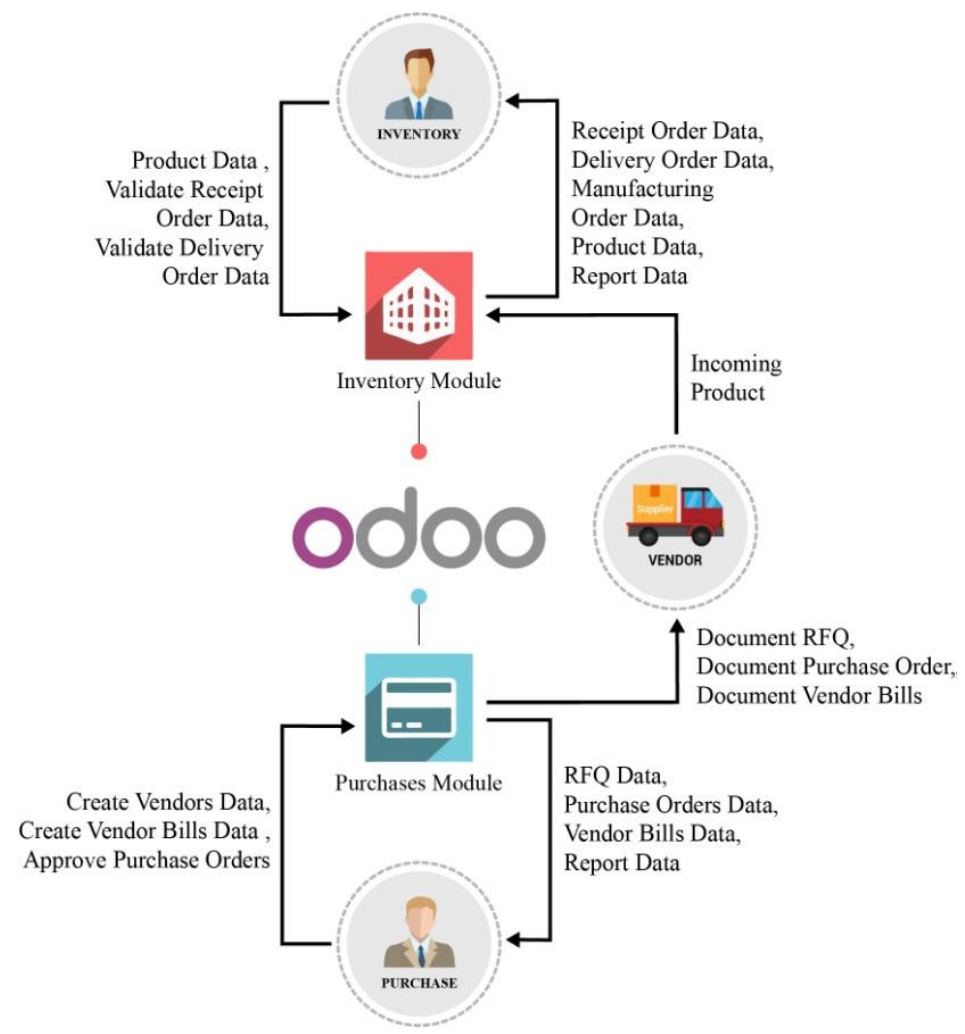

Fig. 2: General Description of the System

There are two modules used in this research which are inventory and purchase module. Inventory Department uses an inventory module to manage warehouse systems such as making product lists, find out the total stock, report data, arrange reordering rules, goods delivery to the customers, etc. The purchase department uses the purchase module to make goods purchasing transactions and manage incoming products. Besides, the Purchase department will give a purchase order document to the Vendor.

\subsection{Initial Configuration}

The initial configuration that must be conducted is Odoo systems are arranging the database configuration, users access rights, and product configuration.

\subsubsection{Database Configuration}

The initial configurations that must be conducted are making the database as storage system of company data and modules used. 


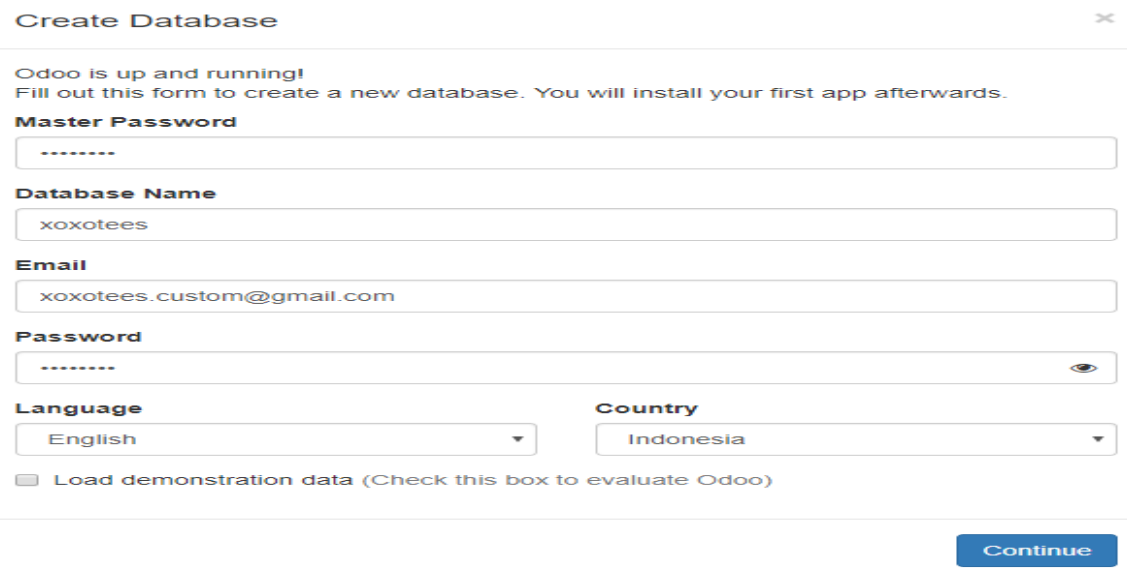

Fig. 3: Database Configuration

The making of this database is conducted by the Administrator by managing Master Password, Database Name, Email, Password, Language, and Country. After that, it is continued to arrange the access rights in each user or company employee who uses Odoo.

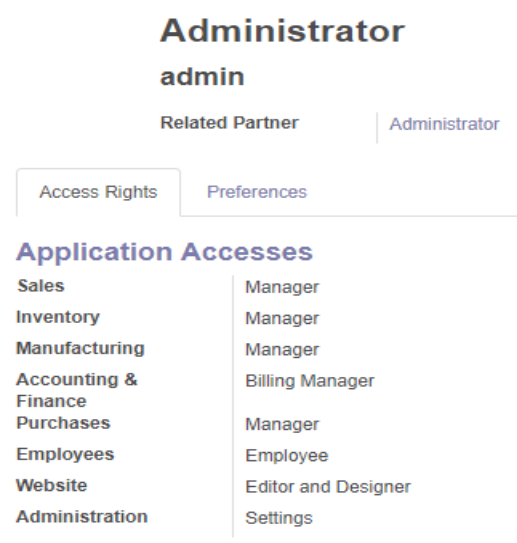

Fig. 4: User Right Access Configuration

The administrator has the right access to all modules and able to make a new user with different access according to positions in the company. There are 4 users who are making to implement the journal which are Inventory Manager, Inventory User, Purchase Manager, and Purchase User.

\subsubsection{User Right Access Configuration}

Create users with different access rights to the Inventory module and Purchase.

\subsubsection{Product Configuration}

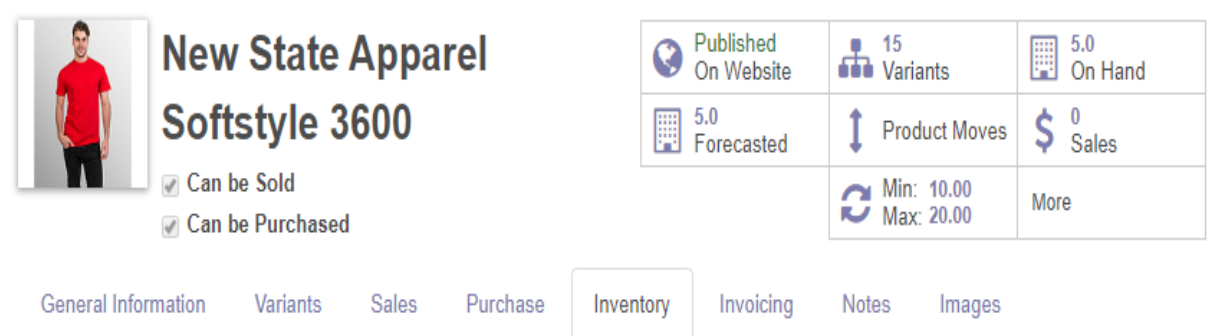

\section{Operations}

\begin{tabular}{l|l} 
Routes & $\square$ Manufacture \\
& $\square$ Buy \\
& $\square$ Make To Order
\end{tabular}

Fig. 5: Product Configuration 
The product in figure 5 is a product sold by the company. Routes used on this product are Buy, which means the procurement system is conducted by buying to the Vendor (supplier). The product stock this time is 5 pcs which can be seen in the On Hand part. After this, the Inventory Manager can manage the reordering rules system of that product by determining the minimum and maximum value of the stock. This configuration is arranged based on the company's needs.

\begin{tabular}{l|l}
\begin{tabular}{l|l} 
Name & OP/00001 \\
Product & [NSA3600-BLK-S] New State Apparel \\
& Softstyle 3600 (Black, S)
\end{tabular}
\end{tabular}

Rules

\begin{tabular}{l|l} 
Minimum Quantity & 10.0
\end{tabular}

Maximum Quantity 20.0

Quantity Multiple $\quad 1.0$

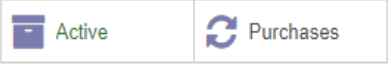

Warehouse

My Company

Product Unit of pcS

Measure

\begin{tabular}{l|l} 
Location & WH/Stock
\end{tabular}

\section{Fig. 6: Reordering Rules Configuration}

The value of minimum stock is set on 10 pcs position and the value of maximum stock is set on 20 pcs-position with quantity multiple as many as $1 \mathrm{pc}$. The lead time part is used to set the time when the product has to be purchased when it reaches the minimum stock position.

\subsection{Business Process Existing}

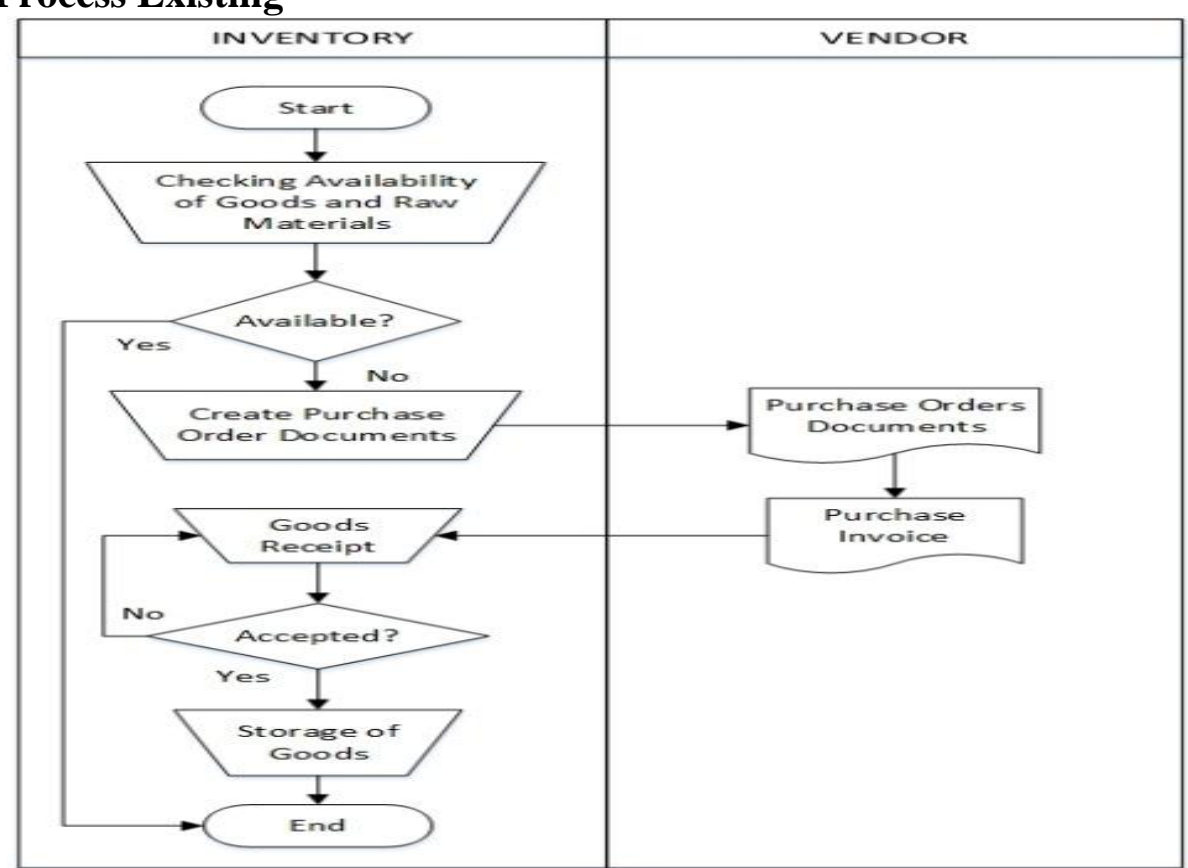

Fig. 7: Current Procurement Business Processes

The procurement process is started from the Inventory department examines the stock condition in the warehouse. If the products are not available, then the product purchase order is made. The purchase-order document is given to the Vendor, the invoice is then given to the Inventory department to conduct payment. When the product is delivered to the warehouse location, the Inventory department examines the product condition whether it is in accordance with the order or not. If it is already in accordance with the order, then the received product can be stored in the warehouse. But if the
The process business that has been implemented between Inventory and Vendor in conducting raw material purchasing can be seen in figure 7. All stages using a conventional manner without an integrated information system such as raw material stock examination, make a purchase order and note the data of raw material reception.
Misc

\begin{tabular}{l|l} 
Lead Time & 1 Day(s) to purchase
\end{tabular} 


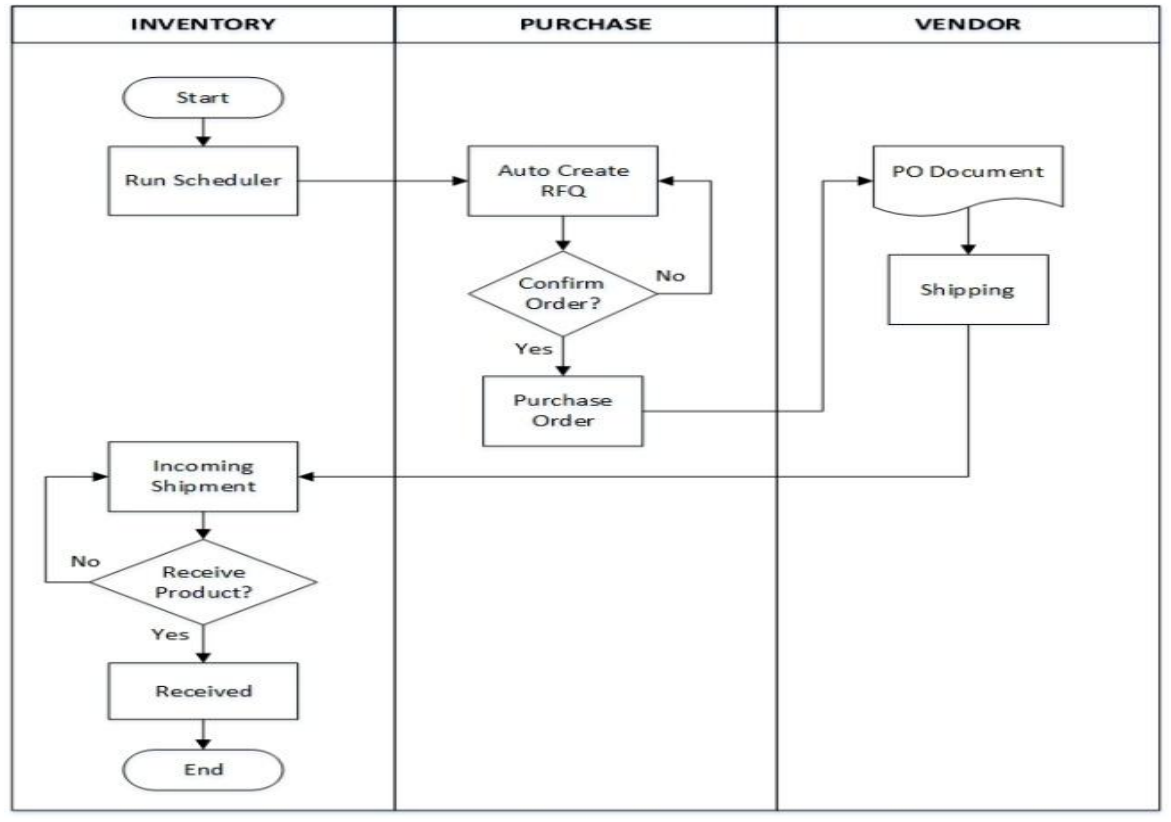

Fig. 8: The Proposed Procurement Processes

Inventory Department runs the run scheduler function in Odoo. Odoo examines the product stock in the system according to rules in the reordering system. Automatically, make product purchasing document draft or called as Request for Quotation (RfQ). This document can be directly received by the Purchase department in purchase module to be examined first before the order is confirmed to purchase order. Then, the Purchase department prints the purchase order document to be sent to the Vendor. Inventory Department waits for the product delivery from the Vendor. After the product has been sent to the warehouse, the Inventory department input the total of the received product from the Vendor on Receipt Document. When all products have been received, then the Inventory will only need to validate on the system and automatically change the stock in the Odoo.

There is a Run Scheduler feature in the Inventory module to make automatically product purchasing in the system. This feature helps the company avoiding mistakes in making the product purchasing order list to fulfill the stock availability in the warehouse. The performance of this feature is by checking reordering rules in every product contained in the system. When the stock is already below the minimum stock, then it will automatically run the procurement system (routes) from the product, such as seen in figure 5 . In this case the routes on the product is Buy, so when running this feature, it will automatically make RfQ or Request for Quotation on the Purchase module.

\section{Request for Quotation}

PO00001

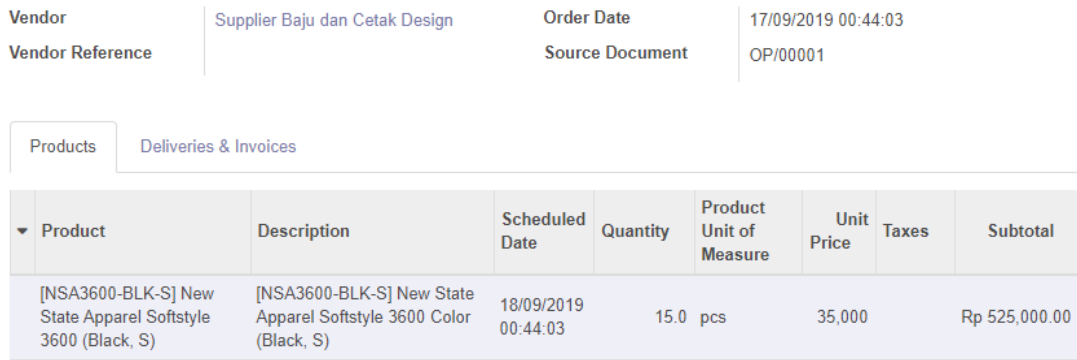

Fig. 10: Request for Quotation

According to reordering rules which are made in figure 10, minimum stock for the products is $10 \mathrm{pcs}$, then the Odoo will automatically make the product purchasing order as many as 15 pcs in fulfilling maximum stock rate which is 20 pcs. Purchase User confirms the purchase order which later will be approved by the Purchase Manager.
After the RfQ document is approved, then the document status changes into Purchase Order (PO). PO document is delivered to the Vendor to order the product. After the ordered product has arrived in the warehouse, the product is delivered to the Inventory User to check the stock availability. 


\section{WH/IN/00001}

\begin{tabular}{|c|c|c|c|c|c|c|c|}
\hline \multicolumn{2}{|c|}{$\begin{array}{l}\text { Partner } \\
\text { Destination Location }\end{array}$} & \multicolumn{2}{|c|}{$\begin{array}{l}\text { Supplier Baju dan Cetak Design } \\
\text { WH/Stock }\end{array}$} & $\begin{array}{l}\text { Scheduled Date } \\
\text { Source Document } \\
\text { Owner }\end{array}$ & \multicolumn{3}{|c|}{$\begin{array}{l}\text { 18/09/2019 00:44:03 } \\
\text { PO00001 }\end{array}$} \\
\hline Operations & \multicolumn{2}{|c|}{ Additional Info } & Note & & & & \\
\hline \multicolumn{4}{|l|}{ Product } & Initial D & & Done & Unit of Measure \\
\hline \multicolumn{4}{|c|}{ [NSA3600-BLK-S] New State Apparel Softstyle 3600 (Black, } & & 15. & 15.0 & pcs \\
\hline
\end{tabular}

Fig. 12: Receipt Order

In the column Done, it shows the total stock which has been received by Inventory User. If all orders have been received, then the Inventory User can validate on the receipt order and automatically renew the total stock in the system such as seen in figure 13 .
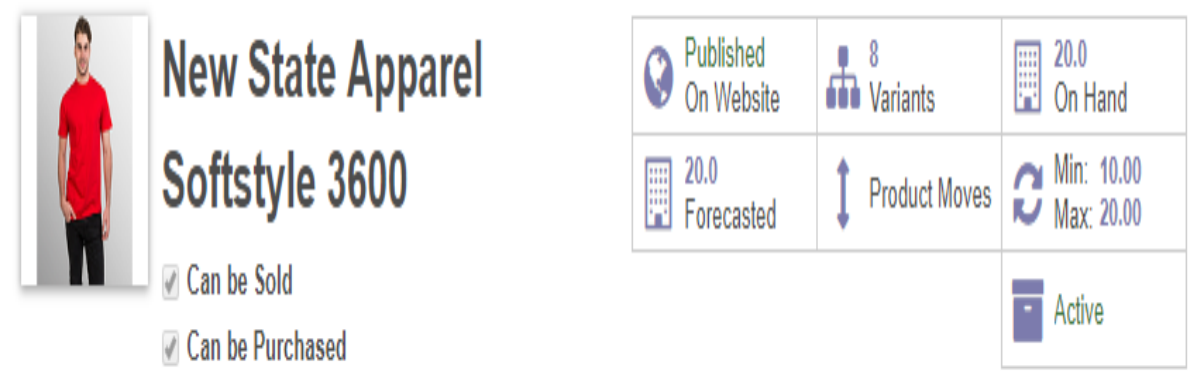

Fig. 13: Stock Updated

Based on figure 13, it can be seen in the current total of the On Hand stock has changed into 20 pcs, according to the rules of maximum stock on reordering rules system.

Table 1. Best Practice Implementation

\begin{tabular}{|c|c|c|}
\hline \multirow{2}{*}{$\begin{array}{c}\text { Business } \\
\text { Unit }\end{array}$} & \multicolumn{2}{|c|}{ Business Process } \\
\hline & Existing & Odoo Implementation \\
\hline \multirow{5}{*}{$\begin{array}{c}\text { Inventory } \\
\text { Department }\end{array}$} & $\begin{array}{l}\text { Data and saved } \\
\text { product information } \\
\text { in the Excel file. }\end{array}$ & $\begin{array}{l}\text { Data and saved } \\
\text { product information } \\
\text { on Odoo database. }\end{array}$ \\
\hline & $\begin{array}{l}\text { Stock recording and } \\
\text { product evaluation } \\
\text { report is conducted } \\
\text { on Microsoft Excel. }\end{array}$ & $\begin{array}{l}\text { Stock recording such } \\
\text { as stock evaluation } \\
\text { report can be seen } \\
\text { directly in the } \\
\text { Inventory module. }\end{array}$ \\
\hline & $\begin{array}{l}\text { Product reception } \\
\text { from the Vendor is } \\
\text { conducted by } \\
\text { changing the stock } \\
\text { recording in } \\
\text { Microsoft Excel. }\end{array}$ & $\begin{array}{l}\text { Product stock changes } \\
\text { automatically when } \\
\text { receipt order has been } \\
\text { validated. }\end{array}$ \\
\hline & $\begin{array}{l}\text { There is no record } \\
\text { for product transfer } \\
\text { report. }\end{array}$ & $\begin{array}{c}\text { There is report feature } \\
\text { for every product } \\
\text { transfer that is } \\
\text { occurred in the sales, } \\
\text { purchases, or goods } \\
\text { production system. }\end{array}$ \\
\hline & $\begin{array}{l}\text { Knowing the } \\
\text { remaining stock in } \\
\text { the warehouse is } \\
\text { conducted by seeing } \\
\text { the Excel file. }\end{array}$ & $\begin{array}{l}\text { Inventory department } \\
\text { can see the remaining } \\
\text { stock report in the } \\
\text { warehouse in the } \\
\text { Inventory module. }\end{array}$ \\
\hline
\end{tabular}

\begin{tabular}{|c|c|c|}
\hline \multirow{3}{*}{$\begin{array}{c}\text { Purchase } \\
\text { Department }\end{array}$} & $\begin{array}{l}\text { Purchasing order- } \\
\text { making is conducted } \\
\text { by recounting the } \\
\text { first stock and } \\
\text { subtracted by the } \\
\text { selling stock total. }\end{array}$ & $\begin{array}{l}\text { Purchase order is } \\
\text { automatically made } \\
\text { based on reordering } \\
\text { rules system in every } \\
\text { product with the stock } \\
\text { minimum and } \\
\text { maximum value. }\end{array}$ \\
\hline & $\begin{array}{l}\text { When the sent } \\
\text { product by the } \\
\text { Vendor is arrived in } \\
\text { the warehouse, the } \\
\text { Purchase department } \\
\text { has to recheck the } \\
\text { product purchase } \\
\text { invoice of the } \\
\text { received product } \\
\text { whether the product } \\
\text { is suitable or not. }\end{array}$ & $\begin{array}{l}\text { There is Incoming } \\
\text { Product function on } \\
\text { the Purchase module } \\
\text { to ease the Purchase } \\
\text { department in } \\
\text { knowing product } \\
\text { information which has } \\
\text { arrived in the } \\
\text { warehouse by the } \\
\text { Vendor. }\end{array}$ \\
\hline & $\begin{array}{l}\text { Data and information } \\
\text { of purchase invoice } \\
\text { is only saved in the } \\
\text { Excel file and when } \\
\text { given to the Finance } \\
\text { department, then the } \\
\text { file has to be printed } \\
\text { first. }\end{array}$ & $\begin{array}{l}\text { Purchase module in } \\
\text { the Odoo helps the } \\
\text { Purchase department } \\
\text { to make vendor bills } \\
\text { draft which is directly } \\
\text { integrated to the } \\
\text { Invoicing module } \\
\text { which is used by the } \\
\text { Finance department } \\
\text { for further process. }\end{array}$ \\
\hline
\end{tabular}

Based on table 1 above, it can be concluded that by implementing Odoo in the company's ongoing business processes has a better impact on companies in the clothing retail industry. Furthermore, a survey stage was performed to determine the readiness of SMEs to accept ERP technology 
named Odoo. This stage was performed based on two variables in the Technology Acceptance Model (TAM) theory, such as perceived ease of use and perceived usefulness. The survey was given to 15 respondents who are SME owners engaged in the clothing retail industry.

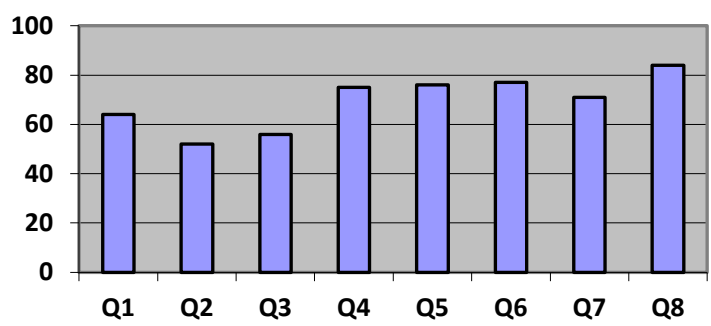

Fig. 14: Performance Rate Statement

The result of the ERP technology survey on the 'perceived ease of use' variable state that $64 \%$ for Q1 'ease of use' statement, 52\% for Q2 'ease to learn' statement and $56 \%$ for Q3 'understandable' statement. The ERP technology on the perceived of usefulness variable state that $75 \%$ for Q4 'work more quickly' statement, $76 \%$ for Q5 'makes job easier' statement, 77\% for Q6 'increase productivity' statement, 71\% for Q7 'effectiveness' statement and $84 \%$ for Q8 'job performance' statement.

\section{CONCLUSION}

The ongoing business processes in the Warehouse department use Microsoft Excel applications to store data on stock information. The Goods Purchasing Department uses Microsoft Excel to create purchasing documents by looking at stock data and sales data. This ongoing business process is still conventional and wastes a lot of time and effort. Nowadays, the development of ERP technology is rapidly developing, it should be implemented by the clothing retail industry SMEs. The application of Odoo to the clothing industry SMEs resulting in a good performance in managing goods data and purchasing raw materials. The Inventory module helps SMEs to manage goods easier and the Purchase module supports to make an order of raw material purchase meant automatically according to the reordering rules system. The existence of this integrated system can reduce human errors that occur in previous business processes, it is because everything is managed in the Odoo system. Odoo which is an open-source helps SMEs in the clothing retail industry to learn using a new business model, especially in the management of purchasing goods for the ones that have reached the minimum amount of stock in the warehouse. The existence of the reordering rules for businessmen can set the minimum and maximum quantities of goods in the warehouse. This feature is run on the run scheduler function in the Inventory module used by the Warehouse staff. Then, the program checks all stock items in the system that are below the minimum stock quantity. After that, the Purchase module is automatically created in a draft purchase order to be submitted to the Vendor. Goods that have been sent by the Vendor are received by the Inventory User to check. If all items have been received in accordance with the purchase order, the receipt order document can be validated and the product stock automatically increases. Then, this study performed a survey stage in the Inventory and Purchase module to find out the readiness of SMEs to accept ERP technology named Odoo based on two variables in the
Technology Acceptance Model (TAM) theory, such as perceived ease of use and perceived usefulness. The results of the survey show that the ERP technology on 'the perceived ease of use' variable on average gets pretty good results at $57 \%$ and on the variable perceived of usefulness the ERP technology on average gets good results at $77 \%$. The results of this questionnaire prove that in terms of perceived ease of use, the ERP technology are quite difficult to use by SMEs due to lack of knowledge or basic ERP concepts. However, in terms of perceived usefulness, if SMEs can apply the ERP technology to business processes, it can reduce errors and speed up data and information needs between departments.

\section{REFERENCES}

[1] E. Monk and B. Wagner, Concepts in Enterprise Resource Planning Fourth Edition, 4th ed. Cengage Learning, 2013.

[2] R. Akbar and J. Juliastrioza, "Penerapan Enterprise Resource Planning (ERP) untuk Sistem Informasi Pembelian, Persedian dan Penjualan Barang pada Toko EMI GROSIR dan ECERAN," Jurnal Nasional Teknologi dan Sistem Informasi, vol. 1, no. 1, pp. 7-17, 2015.

[3] R. Malhotra and C. Temponi, "Critical decisions for ERP integration: Small business issues," International Journal of Information Management, vol. 30, no. 1, pp. 28-37, 2010.

[4] A. L. Tungadi and E. Elisabeth, "Desain Sistem Enterprise Resource Planning untuk Peningkatan Efektifitas Layanan Umat Gereja," JRST (Jurnal Riset Sains dan Teknologi), vol. 2, no. 2, pp. 77-86, 2018.

[5] U. Ruhi and P. Ghatrenabi, "Experiential Learning Spaces for Enterprise Resource Planning Courses in Business Schools," in e-Learning (econf), 2015 Fifth International Conference on, 2015: IEEE, pp. 316-323.

[6] M. Malinova and J. Mendling, "Identifying do's and don'ts using the integrated business process management framework," Business Process Management Journal, 2018.

[7] P. Harmon and B. P. Trends, Business process change: A guide for business managers and BPM and Six Sigma professionals. Elsevier, 2010.

[8] I. H. Firladi, "Pengaruh Prinsip Technology Acceptance Model (TAM) Pada Aplikasi Go-Jek Terhadap Kepuasan Pelanggan (Studi Pada Pengguna Gojek Di Kota Malang)," Universitas Brawijaya, 2017.

[9] F. D. Davis, "Perceived usefulness, perceived ease of use, and user acceptance of information technology," MIS quarterly, pp. 319-340, 1989.

[10] F. Sayekti and P. Putarta, "Penerapan Technology Acceptance Model (TAM) Dalam Pengujian Model Penerimaan Sistem Informasi Keuangan Daerah," Jurnal Manajemen Teori dan Terapan| Journal of Theory and Applied Management, vol. 9, no. 3, 2016.

[11] R. Noprianto, "Studi Literatur Pengintegrasian Dua Metode Kesiapan Dan Penerimaan Pengguna Terhadap Teknologi Informasi Dan Komunikasi," Seminar Nasional Teknologi Informasi dan Komunikasi 2016, 2016. 